\title{
Electric bus in Tyumen: the chase for trends and problems of exploitation
}

\author{
Artur Petrov, ${ }^{1, *}$ and Daria Petrova ${ }^{2}$ \\ ${ }^{1}$ Tyumen Industrial University, Melnikaite street, 72-221, Tyumen, Russia \\ ${ }^{2}$ Federal University named after the first President of Russia B.N. Yeltsin, Ekaterinburg, Chapaev \\ street, 16a-511, Ekaterinburg, Russia
}

\begin{abstract}
The article considers the issues of the progressive development of electric transport in the world and in Russia. The special accent was placed on analysis of electric buses promotion for the city passenger transport market. The history (facts, chronology) of attempts of electric buses exploitation in Russian cities is considered. The information about the technical solutions used in electric buses is given. Data on the economic aspects of electric buses exploitation is presented. We consider the experience of technical exploitation of electric bus LiAZ-6274 in Tyumen and provide information about specifics of technical rejections of this bus during 11 months of usage. President of GAZ Group V. Sorokin and driver of Passenger Motor Transport Enterprise № 1 in Tyumen who worked on the electrical bus gave their opinion on the issues of electric transport in Russia. In conclusion, advantages and drawbacks of electric buses exploitation in Russia at the current moment are considered.
\end{abstract}

\section{Introduction}

The monopolistic era of automobiles with internal combustion engine lasted for more than 100 years. It started on the $9^{\text {th }}$ December 1914 when the fire destroyed Tomas Edison's lab in West Orange, New Jersey and simultaneously all materials and theories connected with independent sources of energy and electric transport [1]. During the work on autonomous sources of power supply, Tomas Edison devoted much attention to the issues of the fast charging accumulators. By the summer of 1914, he started to cooperate with the leader in the automobile industry, Henry Ford. Their goal was the full replacement of the internal combustion engine (ICE), by electromotor, that would lead to being ecocentric and be independent of limited resources in the future. But the next century became the era of automobiles with the ICE. And only 100 years later within the fifth technological paradigm automakers returned to the electric transport.

\footnotetext{
* Corresponding author: ArtIgPetrov@yandex.ru
} 


\section{Overview of the interest to the development of electrical transport in the world}

In the last years electric transport has been actively developing. The reasons of that fact are complex and determined by marketing and ecology considerations. The Electric Vehicle World Sales Database [2] provides the statistics on electric vehicles market as of July 2018.

During the first half of 2018783000 units of electrical transport were delivered, that is $66 \%$ higher than at the same period in 2017. $64 \%$ of electric transport are battery electric vehicles (BEV) and remained $36 \%$ are plug-in hybrids (PHEV).

It's a global average statistic, the relation between amount of BEVs and amount PHEV significantly varies in different countries.

The $88 \%$ of electrotransport market in Netherlands is represented by plug-ins, while there is only $12 \%$ in Finland.

In the whole Europe in the first half of $201851 \%$ of electrotransport was presented by BEVs, in China BEVs stand for $73 \%$. In USA until recent times this number was $53 \%$ but with deliveries of Tesla Model-3 in July BEV share started shifting towards.

Fig. 1a shows the dynamics of electric automobiles market development in the world in $2010 \ldots 2018$. The increase of electric cars amount in China and Europe especially impresses (fig. 1b).
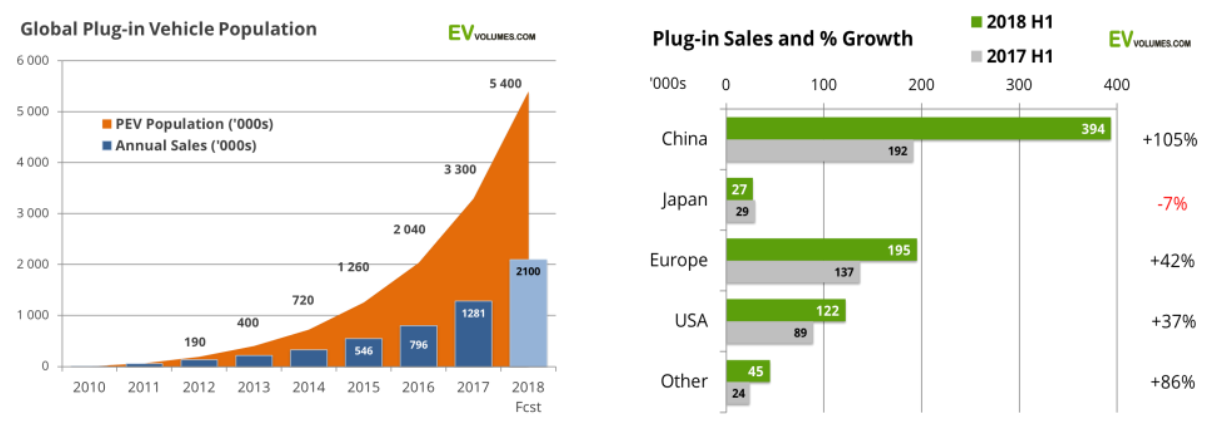

Battery electric vehicles (BEV) / Plug-in hybrids (PHEV)
a) Global growth
b) Growth in some countries

Fig. 1. Electric Vehicle [2, 3].

\section{Russian statistics of electric cars market}

According to the agency «AUTOSTAT» $57 \mathrm{mln}$. vehicle units were registered in Russia at the 01.2018 . In the January 2018 the share of electric transport was $0,00003 \%$ and consists of 1771 units of electric cars and nearly 50 electric buses [4]. The distribution of electric cars among Russian regions is presented in the fig. 2. Electric buses are shown only in Moscow; in other regions electrobuses are exploited only in testing mode with the purpose of finding problems that should be solved, particularly technological rework and optimization of operation modes. 


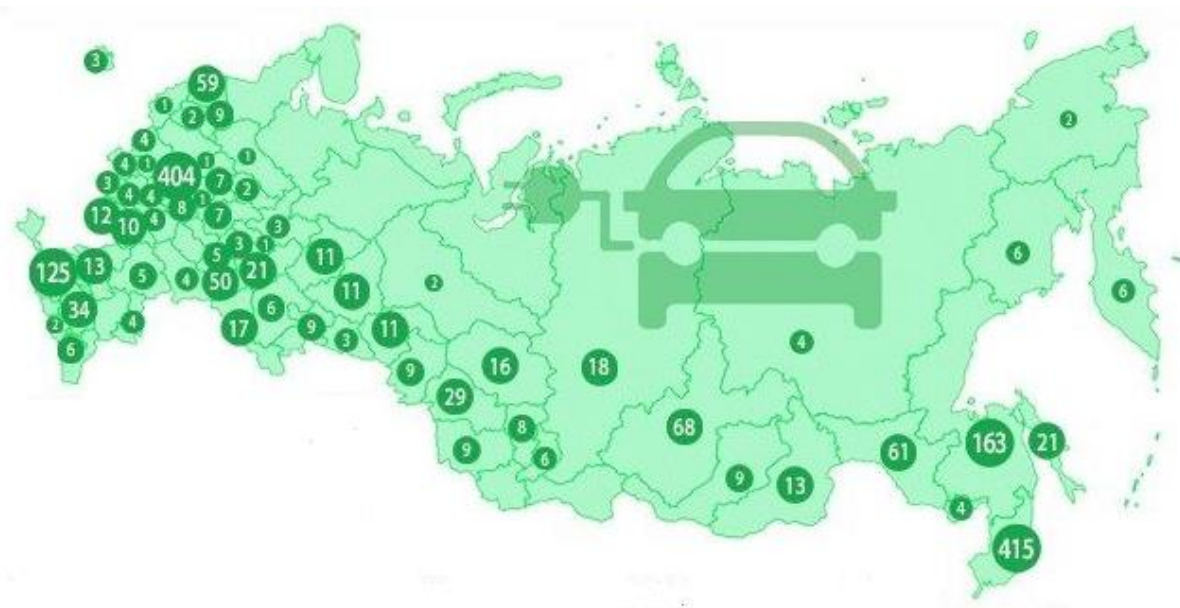

Fig. 2. Localization of electric transport in Russian regions (01. 2018) [4].

Table 1 presents statistics of agency «AUTOSTAT» on/about the most popular models of electric cars in Russia and their predominant localization in regions of country.

Table 1. Statistics of electric vehicles in Russia (01.2018) [5].

\begin{tabular}{|l|c|}
\hline \multicolumn{1}{|c|}{ BEV Models-leaders } & Quantity \\
\hline Nissan Leaf & 1103 \\
\hline Mitsubishi i-MiEV & 283 \\
\hline Tesla Model S & 194 \\
\hline LADA Ellada & 93 \\
\hline Tesla Model X & 68 \\
\hline Renault Twizy & 26 \\
\hline BMW i3 & 4 \\
\hline Electric buses & 8 \\
\hline Total & $\begin{array}{l}1771 \text { cars }+8 \\
\text { electric buses }\end{array}$ \\
\hline
\end{tabular}

\begin{tabular}{|l|c|}
\hline \multicolumn{1}{|c|}{ Leading regions } & Quantity \\
\hline Primorsky region & 415 \\
\hline Moscow & 328 \\
\hline Khabarovsky region & 163 \\
\hline Krasnodar region & 125 \\
\hline Moscow region & 76 \\
\hline Irkutsk region & 68 \\
\hline Amur region & 61 \\
\hline Saint-Petersburg & 59 \\
\hline Other regions & 476 \\
\hline Electric buses & 8 \\
\hline
\end{tabular}

\section{Electric buses in Russia: history of development and statistics}

First official results of electric buses production were presented in 2012 [6]. GAZ Group showed first domestic electric bus ЛИА3-6274 at the International bus saloon «Busworld Russia - 2012» that took place in Nizhny Novgorod.

During next five years car manufacturers had worked on rework of powertrain construction and accumulators of electric buses. Then performance testing began. Electric bus KAMAZ-2257E (fig. 3) during couple years (2015...2017) was exploited in test mode in Naberezhnye Chelny. Today it is working in Innopolis (Tatarstan). Electric bus KAMAZ-6282 (fig. 4) passed operational tests in Naberezhnye Chelny (2016...2017), Kazan (2017...2018) and Rostov-on-Don (2017...2018). 


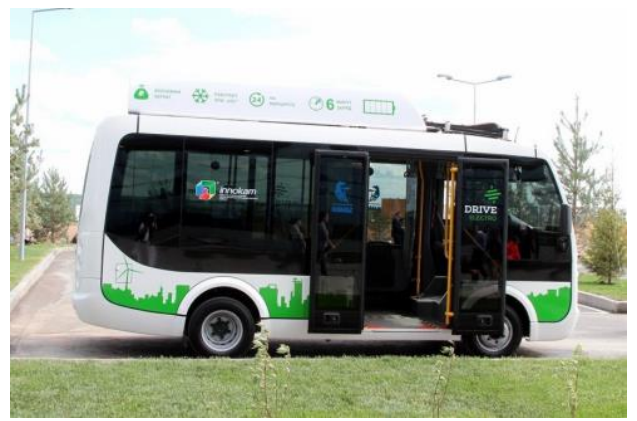

Fig. 3. The electric bus KAMAZ-2257E (Naberezhnye Chelny).

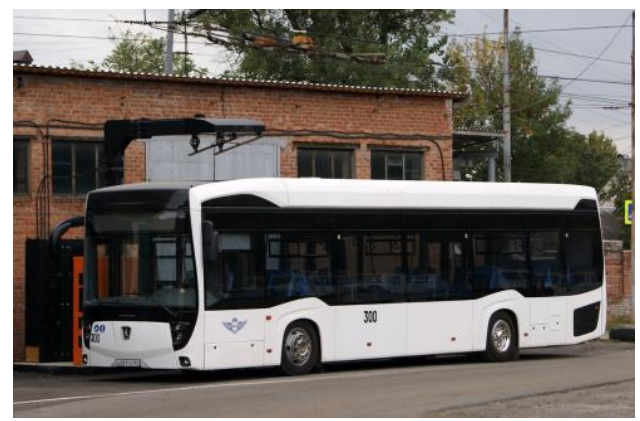

Fig. 4. The electric bus KAMAZ-6282 (Rostov-on-don).

Electric buses Volgabus City-Rhythm 12E (5270E) in 2017...2018 passed tests in cities of Central Federal District, Volga Federal District, Siberian Federal District and Ural Federal District. One of them worked in test mode in Lipetsk, Volgograd, Vladimir, Tula, Izhevsk, Kazan (fig. 5...6). The second at the same time worked in Novosibirsk, Surgut, Khanty-Mansiysk and Perm.

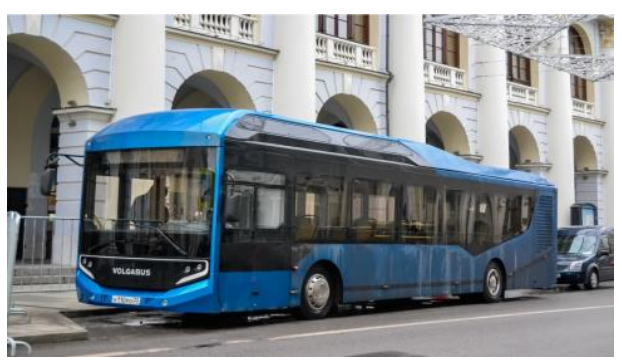

Fig. 5. The electric bus Volgabus City-Rhythm $12 \mathrm{E}$ (Vladimir).

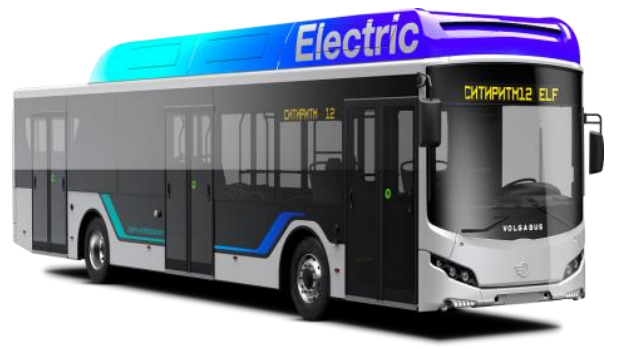

Fig. 6. The electric bus Volgabus City-Rhythm $12 \mathrm{E}$ (promotional photo).

At the winter of 2017...2018 in Odintsovo (Moscow region) in SkolTech small class electric bus Next Electro-7720 (fig. 7) was started to be used. In Tyumen during 11 months of 2018 electric bus LIAZ-6274 (fig. 8) worked on city route in operational mode.

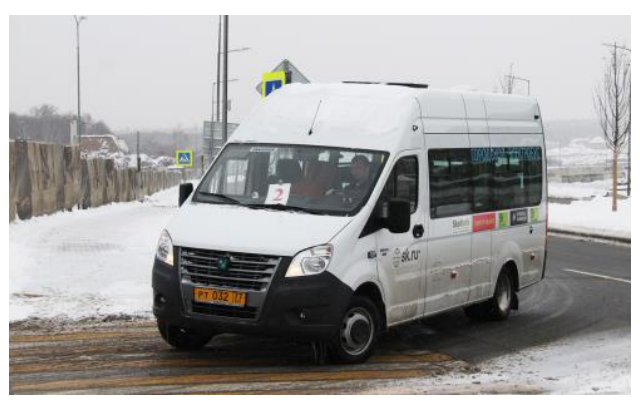

Fig. 7. The electric bus Next Electro-7720 Odintsovo (Moscow region).

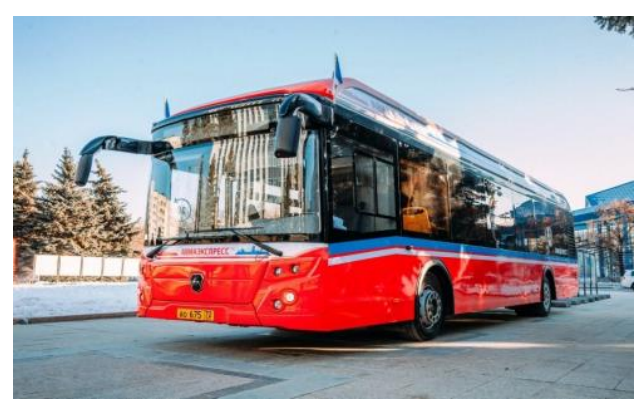

Fig. 8. The electric bus LiAZ-6274 (Tyumen).

In Saint-Petersburg and Tambov electric buses BKM U 433 Vitovt Max Electro (JSC «Belkommunmash») still have been testing. 


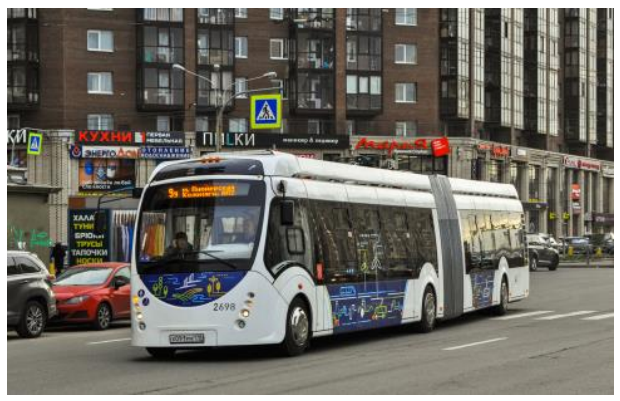

Fig. 9. The electric bus BKM U 433 Vitovt Max Electro (Saint-Petersburg).

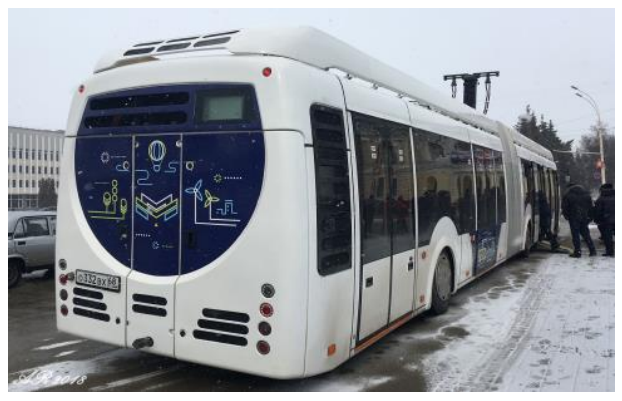

Fig. 10. The electric bus BKM U 433 Vitovt Max Electro (Tambov).

In May 2018 Moscow City Hall held a tender for procurement of 200 electric buses. As a result of competition production and delivery of electric buses for Moscow was equally divided between JSC «KAMAZ» and JSC «Russian Buses - GAZ Group». Contract value of one electric bus is $33 \mathrm{mln}$. rub., however general cost of 200 electric buses is $12,7 \mathrm{bln}$. rub. That sum also covers construction of 62 charging stations and technical service of buses and infrastructure during next fifteen years.

1.09.2018 the exploitation of electric buses in Moscow began (fig. 11) at first on one city route, then on five.
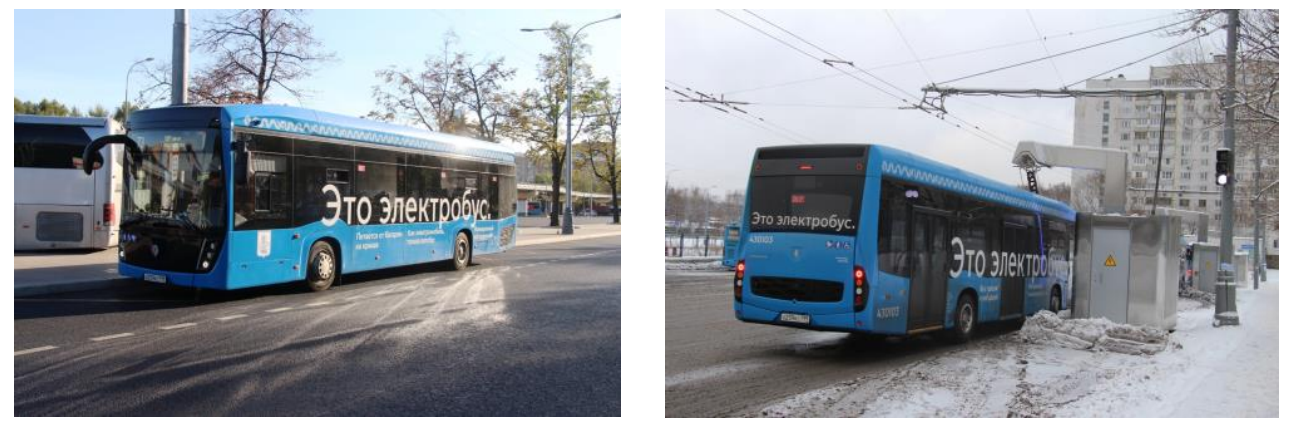

Fig. 11. The electric bus KAMAZ-6282 (Moscow).

\section{Electric buses LiAZ: technical solutions}

Official release of LiAZ-company [7] describes next information about technical solutions, used in electric bus LiAZ-6274.

The main components of electric bus equipment are:

- Lithium-ion batteries «LioTekh» that provides high energy density, exploitation safety, long service life and wide range of working temperature. Characteristics of batteries allows to execute the fast charge (up to $70 \%$ of capacity in 20 minutes) without significant reduction of life duration.

- Battery Management System (BMS) that intended for control of parameters of accumulator operating mode and state of individual cells. BMS also performs next functions:

- Control and management of accumulator battery charge process;

- Defence of battery from extraordinary operating mode;

- Balancing of accumulator battery. 
- Indication display represents information about current operating mode, state of accumulator battery and main components of power circuit (power sources, power cable, motor controller).

- Traction asynchronous electric motor that transforms electrical energy in kinetic energy of electric bus. In the recuperation mode it provides partial return of electrical energy to accumulator battery.

- Traction inverter works in the mode of vector control of electrical motor that allows to achieve high accuracy and efficiency of speed and torque engine regulation. It also provides high energy conversion efficiency through minimization of losses on heating and remagnetization.

- Charging device that provides charge of accumulator battery with direct current. Traction inverter is used as charging devices, it gets nutrition from three-phase electrical grid with $380 \mathrm{~V}$ voltage.

\section{Economics of electric buses exploitation}

At [8] Moscow transport department official data on calculated specific operational expenses per $1 \mathrm{~km}$. of electric bus mileage (regardless of model) is given. This data and analogous one about diesel buses LiAZ-5293, exploited in Tyumen, are shown in table 2.

Table 2. Operating costs per $1 \mathrm{~km}$.

\begin{tabular}{|c|c|c|}
\hline \multirow[b]{2}{*}{ Indicator } & \multicolumn{2}{|c|}{ Numerical value, RUB / km } \\
\hline & $\begin{array}{l}\text { Electric bus } \\
\text { (Moscow) }\end{array}$ & $\begin{array}{l}\text { Diesel bus } \\
\text { (Tyumen) }\end{array}$ \\
\hline Energy costs & 8.2 & 14.5 \\
\hline Amortization & 35.2 & 9.4 \\
\hline Infrastructure maintenance & 12.5 & 0.2 \\
\hline Other operating costs (all items except salary) & 36.5 & 14.2 \\
\hline Total & 92.4 & 38.3 \\
\hline
\end{tabular}

Almost threefold difference between calculated standards of $1 \mathrm{~km}$. mileage cost of the electric bus and diesel bus doesn't support electric buses.

\section{Problems of exploitation of electric buses in Russia}

President of «GAZ Group» V. Sorokin named the decision of Moscow about procurement of 300 electric buses as political euphoria that doesn't consider Russian climate. V. Sorokin said: «At temperature below than minus $20{ }^{\circ} \mathrm{C}$ degrees $80 \%$ of electric bus accumulator energy goes to heating of windshield, rear-view mirrors and driver's seat. Saloon can't be heated. And $20 \%$ of energy is used for movement».

\section{The experience of electric bus LiAZ-6274 exploitation in Tyumen}

In order to study the advantages and drawbacks of electric buses in real exploitation conditions Tyumen Town Hall decided to buy electric bus LiAZ-6274 that costs nearly 32 mln. rub. (the cost of analogous large class diesel bus LiAZ-5293 is nearly 9,5 mln. rub.)

Electric bus LiAZ-6274 had worked in the mode of everyday exploitation for 9 months (put in service on 27.12.2017, withdrawn from service on 03.10.2018). Electric bus worked 
on Tyumen route № 10 that connects airport, railway station and bus station. Actual mileage was $16879 \mathrm{~km}$, bus worked for 93 days and made 930 voyages, while according to the plan it had to work for 203 days and should have made 2030 voyages. Thus, the regularity of electric bus work (relation between accomplished and planned voyages) is $45.8 \%$. The main reasons of the low bus efficiency coefficient are technical rejections and as the consequence awaiting of repair. According to the terms of the service contract repair should be carried out by specialists from LiAZ. Table 3 gives data on rejections of electric bus LiAZ-6274 that were registered during exploitation in Tyumen.

Table 3. Technical rejections of electric bus LiAZ-6274 during the exploitation.

\begin{tabular}{|c|c|c|}
\hline Date & External demonstration of defect & $\begin{array}{l}\text { Short description of repair work } \\
\text { performed by specialists from LiAZ- } \\
\text { company }\end{array}$ \\
\hline \multicolumn{3}{|c|}{ Actual mileage $0 \ldots 16879 \mathrm{~km}$} \\
\hline 17.01.2018 & $\begin{array}{l}\text { Fluid in the system of steering booster } \\
\text { got frozen at }-20^{\circ} \mathrm{C} \text {. }\end{array}$ & Replacement of steering booster fluid. \\
\hline 18.02.2018 & $\begin{array}{l}\text { Vibration and knocking on the front } \\
\text { while bus is moving. }\end{array}$ & $\begin{array}{l}\text { Removal / instalment of anti-roll bar, } \\
\text { replacement of bar's pillow-blocks. } \\
\text { Removal / instalment of tie rod, } \\
\text { replacement of tie rod's tips. }\end{array}$ \\
\hline 01.03 .2018 & $\begin{array}{l}\text { Diagnostics, held by LiAZ-company } \\
\text { squad, showed demand of traction } \\
\text { accumulator block recovery. }\end{array}$ & $\begin{array}{l}\text { Replacement of traction accumulator } \\
\text { block. }\end{array}$ \\
\hline 18.05.2018 & $\begin{array}{l}\text { Disrepair of two traction accumulator } \\
\text { blocks. Fast discharge of accumulator } \\
\text { blocks while bus is moving. }\end{array}$ & $\begin{array}{l}\text { Replacement of two traction } \\
\text { accumulator blocks. }\end{array}$ \\
\hline 04.07.2018 & $\begin{array}{l}\text { Climatic system (air conditioning) } \\
\text { didn't work. }\end{array}$ & $\begin{array}{l}\text { Pressure testing, vacuuming and filling } \\
\text { of conditioner with freon was done. } \\
\text { Repair of climatic system electrical } \\
\text { equipment. }\end{array}$ \\
\hline 06.07 .2018 & Glass washer motor didn't work. & Replacement of glass washer motor. \\
\hline 31.07.2018 & $\begin{array}{l}\text { Two blocks of accumulator battery } \\
\text { overheated. }\end{array}$ & $\begin{array}{l}\text { Diagnostics and replacement of } \\
\text { accumulator } \\
\text { ventilators. }\end{array}$ \\
\hline 05.09 .2018 & $\begin{array}{l}\text { Disrepair of third traction accumulator } \\
\text { block. }\end{array}$ & $\begin{array}{l}\text { Replacement of traction accumulator } \\
\text { block. }\end{array}$ \\
\hline 13.09.2018 & $\begin{array}{l}\text { Overheating of four accumulator } \\
\text { blocks. Accumulators can't charge until } \\
\text { they cool down. }\end{array}$ & Repair by LiAZ-company squad. \\
\hline 22.09 .2018 & $\begin{array}{l}\text { Disrepair of second and third traction } \\
\text { accumulator blocks. }\end{array}$ & Repair by LiAZ-company squad \\
\hline
\end{tabular}

\section{Expert opinion of the driver of Tyumen Passenger Motor Transport Enterprise № 1 that drove electric bus in Tyumen}

In general expert opinion of the driver about electric bus LiAZ-6274 is positive. The driver noted a high level of comfort, the absence of vibration and noise, smoothness of running and braking, fast racing of the engine. In winter and in summer specific problems connected with temperature conditions arise. At high temperatures (higher than $25{ }^{\circ} \mathrm{C}$ ) accumulator batteries inefficiently cool and, as the consequence, overheat. In the winter saloon can't be heated up. Diesel heater copes with this function but the electric bus has the ecological advantage. In the winter power consumption increases not significantly (by $5 \ldots 10 \%$ ) and it's a good result for Tyumen climate. 


\section{Conclusion}

1. Russia is making attempts to transit to new transport and logistics technology which include electrical buses. Usage of public electrotransport with improve ecological situation in Russian cities [9-10].

2. But at the same time there are two big problems in the sphere if electric transport:

- High cost of electric buses;

- Low reliability of electric buses in exploitation.

Solutions of these two problems are interconnected. Improvement of construction and growth of consumers' interest in electric buses will lead to increasing production up to industrial scale and that will decrease cost and increase demand on electric buses.

3. The elimination of technical defects and the adaptation of electrical bus design to the conditions of the Siberian winter can lead to displacement of buses with internal combustion engine (ICE) by electrical buses like LiAZ-6274. This is the point of view of professional driver with 20 years of experience.

\section{Reference}

1. E. Black, Internal combustion (Publishing house «Good book», Moscow, 2010)

2. http://www.ev-volumes.com/

3. http://www.ev-volumes.com/country/total-world-plug-in-vehicle-volumes/

4. https://elmobil.ru/\%D1\%81\%D0\%BA\%D0\%BE\%D0\%BB $\%$ D $1 \% 8 \mathrm{C} \% \mathrm{D} 0 \% \mathrm{BA} \% \mathrm{D} 0 \%$ BE-\%D1\%8D $\%$ D0\%BB\%D0\%B5\%D0\%BA\%D1\%82\%D1\%80\%D0\%BE\%D0\%BC $\% \mathrm{D} 0 \% \mathrm{BE} \% \mathrm{D} 0 \% \mathrm{~B} 1 \% \mathrm{D} 0 \% \mathrm{~B} 8 \% \mathrm{D} 0 \% \mathrm{BB} \% \mathrm{D} 0 \% \mathrm{~B} 5 \% \mathrm{D} 0 \% \mathrm{~B} 9-\% \mathrm{D} 0 \% \mathrm{~B} 2-\% \mathrm{D} 1 \% 80$ $\%$ D0\%BE\%D1\%81\%D1\%81\%D0\%B8\%D0\%B8-\%D0\%BD\%D0\%B0-2018$\% \mathrm{D} 0 \% \mathrm{~B} 3 /$

5. https://elmobil.ru/wp-content/uploads/2018/04/9fe440ef-670-0-e1523358383596.jpg

6. https://carsguru.net/news/12317/view.html

7. http://liotech.ru/UserFiles/presentations/Leaflets/Liotech_Listovka_LIAZ_A4.pdf

8. https://www.mos.ru/mayor/themes/2299/4977050/

9. A.I. Petrov, D.A. Petrova, IOP Conf. Ser.: Earth and Environmental Science 72, 012007 (2017)

10. A.I. Petrov, D.A. Petrova, IOP Conf. Ser.: Earth and Environmental Science 181, 012025 (2018) 